\title{
Financial Stability of Conventional and Islamic Banks: Empirical Evidence
}

\author{
Ilyes Abidi (Corresponding author) \\ University of Tunis El Manar, Tunisia \\ E-mail: abidi.elyes@hotmail.fr \\ Mariem Nsaibi \\ University of Hail, Saudi Arabia \\ Boutheina Regaieg \\ Faculty of Law, Economics and Management of Jendouba \\ University of Jendouba, Tunisia
}

Received: December 17, 2019 Accepted: January 10, 2020 Published: March 10, 2020

doi:10.5296/ijafr.v10i1.16059 URL: https://doi.org/10.5296/ijafr.v10i1.16059

\begin{abstract}
The aim of this paper is to study the stability of Islamic banks vs. conventional banks. Unlike previous works on this topic, we used profitability, solvency, productivity, investment and risk indicators, as well as macroeconomic indicators. Likewise, we used effectiveness and efficiency indicators, determined via the SFA and DEA method respectively.

The banks in our sample were selected based on their contribution to the total assets of both types of finance. This selection method allowed us to have a global idea on the effectiveness, efficiency, risk and stability of the two banking sectors.

This empirical investigation revealed that Sharia-compatible banks are more efficient than conventional banks. In contrast, Islamic banks are less efficient and riskier than conventional banks. They lose on average $5.795 \%$ and $3.9413 \%$ of their assets, respectively, as credit risk and operational risk. In terms of market risk, Islamic banks are less risky than conventional banks. They lost 3,214\% of their assets over the 2004-2014 period, compared with 4,119\%
\end{abstract}


for conventional banks.

All in all, the two types of institutions were able to resist the crisis despite the slight reduction in activity and the minimal decrease in their stability scores due to the decline in activity and the prudent policy they adopted.

Keywords: Effectiveness, Efficiency, Risk and stability

\section{Introduction}

Islamic finance is an ethical alternative to conventional finance. It is characterized by the prohibition of interest and usury, and the sharing of profits and losses. From its appearance and especially after the explosion of the price of oil, Islamic finance knows a meteoric growth.

In the wake of the 2007 crisis, several financial markets have been interested in Islamic finance in order to drain liquidity and finance their economy. Despite this financial situation, regulatory frameworks have been set up to attract Islamic banks. In this regard, Islamic finance has grown significantly around the world and has emerged as an alternative to the conventional financial system. To this end, this field of research has become the main concern of many specialists and supervisory authorities. These have shown that Islamic finance is a way of regulating the economy. We quote in this context, the work of Askari .H and Krichene, N. (2014), Alam, S. (2015) Isik and Hasan (2002, 2005), Ali Said (2012) and Rao, K. (2015).

Although the financial literature is rich in works on the stability of Islamic banks, they do not lead to a consensus and the results are mixed. In fact, the main disparity between these works is in the samples and the variables used. However, previous works has not included variables reflecting financial risks in their regression models. Likewise, they did not use scores to analyze effectiveness and efficiency, and limited themselves to the use of ratios. It is in this context that we need to shed new light, through an empirical study, by testing the financial stability of the two types of banks (Islamic versus conventional). In this regard, this research paper comes to enrich the financial literature since it provides empirical evidence on the stability of Islamic banks. To do this, we will study the effectiveness and the efficiency of 20 Islamic banks and 20 conventional banks. Then, we will determine their respective stability scores. The choice of these banks is justified by their contribution to the total assets of the both types of finance. The rest of the paper is organized as follows: The first section is reserved for the presentation of the main works on this subject. The second section is devoted to the description of the data, the variables and the methodology used. Finally, in the third section, we will present and discuss the main results obtained.

\section{Literature Review}

The majority of the studies on this topic have focused on the performance of Islamic banks during the crisis period. According to Burchan, S. (2016), Rajhi, W. and Hassairi, S. A. (2013) Siamak, S. F. and al. (2014) Abd Elrahman Elzahi, A. S. (2011), Boumediene, A. and Caby, J. (2009), Islamic banks tend to have a higher level of stability compared to conventional banks. 


\section{Macrothink}

International Journal of Accounting and Financial Reporting ISSN 2162-3082 2020, Vol. 10, No. 1

Mosab I. Tabash and Raj S. Dhankar (2015) studied the ability of the banking sector of the GCC Countries (United Arab Emirates, Saudi Arabia, Bahrain and Qatar) to absorb financial shocks. They assessed the impact of the global financial crisis on the "Liquidity Ratios" and "Capital Adequacy Ratios". The results indicated that Islamic banks hold more liquid and less risky assets than conventional banks. The analysis of variance (ANOVA) shows that there was no significant difference between Islamic banks' ratios before, during and after the financial crisis.

Mustafa, H. M., and al. (2013) indicated that there was no significant difference between the financial stability of the two types of banks for the period 2003-2010. However, conventional banks tend to be financially more robust than Islamic banks for the pre-crisis period (2003-2006). In contrast, during and after the crisis, Islamic banks were more stable than conventional banks despite falling oil prices.

Hatem Hatef, A. A., and al. (2013) studied the stability of Islamic banks and conventional banks in the GCC countries between 2003 and 2010 while examining the impact of the crisis on them. The analysis revealed that there was no significant difference between the two types of banks. In fact, over the period 2005-2010, conventional banks lost value by increasing their non-performing credit provision funds. This allowed the Islamic banks to achieve a better return. In contrast, the Okumus, H. S., and Artar, O. K. (2012) study found that large conventional banks were more stable than larger Islamic banks while smaller Islamic banks had better stability than smaller conventional banks. By and large, Islamic banks are not immune to crises because they have been impacted by the downsizing of oil companies and they are in the early stages of risk management.

Gamaginta and Rokhim, R. (2011) individually measured the stability levels of 12 Islamic banks and 71 conventional banks in Indonesia. The results of the study showed a weak stability of Islamic banks compared to conventional banks. In the crisis period, conventional banks have experienced a low level of stability, unlike Islamic banks which have kept the same trend and this because of their high level of liquidity reserve and their ability to channel available funds to the most profitable production sectors. However, Islamic windows were more stable than small Islamic banks, but there was no significant difference in terms of stability. Reflecting the challenges of risk management and banking supervision, large Islamic banks are less stable than large conventional banks (Gamaginta, D., and Rokhim, R. (2011), Solé, J., (2007) and Errico, L., and Farrahbaksh, M. (1998)). In other words, the Islamic banking sector cannot benefit from economic growth because it can financially weaken its stability (Imam, P., and Kpodar, K. (2010)). In Malaysia, for cons, Islamic banks are on average more stable than conventional banks (Hassan, M. N., and al. (2012)). In the same vein, Rahim and Zakaria (2013) studied the stability of 17 Islamic banks and 21 conventional banks during the period 2005-2010. Using an analysis of panel data, they concluded that Islamic banks are more stable and their assets have not been infected with the "credit subprime".

According to Benaissa, E. N., Parekh, M. P., and Wiegand, M. (2005), in order for a banking system to be stable, decision-makers must maintain the balance between supply and demand 


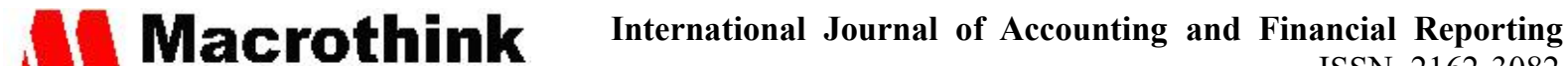 ISSN 2162-3082 2020, Vol. 10, No. 1}

and perceive an adequate concentration of business (household, enterprise). In the same section, Muhammad, R. and al. (2012) examined the stability of the Pakistani banking system to see if Pakistan has managed to profit from Sharia-compatible finance. This work indicated the existence of an inherent growth of banking stability thing which resulted in the growth of the size of Pakistani banks. Moreover, the analysis of the size, investment, performance and deposit indicators indicates that Islamic banks in Pakistan have weathered the 2007 crisis and that small Islamic banks are more stable than large Islamic banks and small conventional banks. Overall, Islamic banks are less stable than conventional banks. In fact, this work was based on that of Hasan and Dridi (2010) who used profitability, loan growth, asset growth, and the environmental aspect to study the stability of 85 conventional banks and 37 Islamic banks between 2005 and 2009. The empirical study by Hassan and Dridi (2010) revealed that the protectionist aspect that stems from the Islamic economic model has not made it possible to limit the negative impact of the crisis. This finding stems from the fact that some Islamic banks have shortcomings in risk management practices which has influenced their profitability and even their stability score. Also, Bourkhis and al. (2010) analyzed the stability of 407 banks from 19 countries between 1993 and 2009. In contrast to the work of Cihak and Hesse (2008), the estimation results reveal that Islamic banks are more stable than conventional banks.

Indeed, according to Thorsten, B., Asli, D. K., and Ouarda. M. (2010) what made the difference in terms of stability was the mass of liquidity held by Islamic banks, their large capitalization and the importance of their capital. Otherwise, Sayd, F., Kabir, M. H., and Gregory, C. (2014) stated that the distribution of profits, the level of concentration of fixed rate assets, the level of profit sharing and the existence of optional reserves are the key factors of financial stability. Given the work of Cihak and Hesse (2008), Sayd, F., Kabir, M. H., and Gregory, C. (2014) estimated and compared the stability levels of 37 Islamic banks and 150 classic banks covering 17 countries. This work indicated that the asset size and the optional reserves negatively impact the stability, but paradoxically the increase in the "Cost to Income" ratio improves the z-score. Sayd, F., Med Kabir, H., and Gregory, C. (2014) described the positive relationship between the Cost-to-Income ratio and the z-score as a paradox because Islamic banks invest through the sharing of profits and losses. This exposes them to uncertain returns which potentially increases the risk and reduces the z-score. From the point of view insolvency risk, Pejman, A., Philip, M., and Tarazi, A. (2011) stated that despite the difference between the financing and investment modes of the two types of banks, there was no significant difference between Islamic banks and conventional banks. However, since Islamic banks are less exposed to insolvency risk than conventional banks, they accept a high credit risk. As such, Islamic funds are riskier than conventional funds, small Islamic banks are more stable than conventional small banks and large conventional banks are more stable than large Islamic banks.

From a critical point of view, works previously presented in the literature review lack risk and performance indicators or use non-tangible indicators of risk, efficiency and effectiveness. To decline these limits, we have made a score composed of indicators of effectiveness, efficiency, profitability, solvency, productivity, investment and risk, as well as macroeconomic 
indicators.

\section{Methodology}

The aim of this paper is to study the stability of Islamic banks vs. conventional banks. Unlike previous work, we calculated the efficiency and effectiveness scores, using the SFA and DEA method, instead of using ratios reflecting these two indicators. Then, the efficiency and effectiveness scores were used together with the profitability, solvency, productivity, investment and risk indicators, as well as macroeconomic indicators, in order to calculate the stability scores for the two types of banks (Islamic and conventional).

The stability scores of the two types of banks will be calculated using the scoring method. The respective z-scores can be written as follows:

$$
\begin{aligned}
\mathrm{L}_{\mathrm{B}} & =\alpha+\beta_{1} \mathrm{CE}_{\text {it }}+\beta_{2} \mathrm{PE}_{\text {it }}+\beta_{3} \mathrm{TE}_{\text {it }}+\beta_{4} \mathrm{ROE}_{\text {it }}+\beta_{5} \mathrm{SR}_{\text {it }}+\beta_{6} \mathrm{CTI}_{\text {it }}+\beta_{7} \mathrm{INT}_{\text {it }} \\
& +\beta_{8} \mathrm{MR}_{\text {it }}+\beta_{9} \mathrm{CR} \text { it }+\beta_{10} \mathrm{OP}_{\text {it }}+\beta_{11} \mathrm{Ln}(\mathrm{TA}) \text { it }+\beta_{12} \mathrm{INF} \text { it }+\varepsilon_{\text {it }}
\end{aligned}
$$

Then, we will use the exponential transformation of the logit model to derive the respective stability levels of Islamic and conventional banks. This probabilistic relation can be expressed as follows:

$$
\mathrm{W}_{\mathrm{i}}=\frac{1}{1+\operatorname{Exp}^{-\mathrm{L}}}
$$

The respective levels of efficiency and effectiveness of Islamic and conventional banks were determined using the DEA and SFA methods, respectively. The choice of these methods is not arbitrary but is justified by the relevance and precision of their results (Laurent Weill (2002), Resti, A. (1997), Berger and al. (1997), Vander, V. (1996), Drake and Weyman-Jones (1996) and Ferrier and Lovell (1990)). The DEA method is written as follows (Note 1):

$$
\begin{gathered}
\operatorname{Max} \frac{\sum_{k=1}^{s} V_{k} Y_{k p}}{\sum_{j=1}^{m} U_{j} X_{j p}} \\
\text { U.C: } \frac{\sum_{k=1}^{s} V_{k} Y_{k i}}{\sum_{j=1}^{m} U_{j} X_{j i}} \leq 1 \quad \forall i
\end{gathered}
$$

With: $\mathrm{Vk}, \mathrm{Uj} \geq 0 \forall \mathrm{k}, \mathrm{j}$

Where: $\mathrm{k}=1 \ldots \mathrm{s}, \mathrm{J}=1 \ldots \mathrm{m}, \mathrm{I}=1 \ldots \mathrm{n}$

$\mathrm{Xji}=$ Price of $\mathrm{j}$ input used by $\mathrm{i}$ DMU.

$\mathrm{Y}_{\mathrm{ki}}=$ Price of $\mathrm{k}$ output produced by i DMU.

$\mathrm{V}_{\mathrm{k}}=$ Weighting attributed to output.

$\mathrm{U}_{\mathrm{j}}=$ Weighting attributed to the input.

Unlike the DEA method, the SFA method admits a parametric form which is presented as 
follows:

$\operatorname{Ln} C=f(w, y)+V_{c}-U_{c}$

$\mathrm{C}=$ Total cost.

$\mathrm{W}=$ Inputs Vector.

$\mathrm{Y}=$ Outputs Vector.

$\mathrm{V}_{\mathrm{c}}=$ Error component.

$\mathrm{U}_{\mathrm{c}}=$ Ineffective component.

In our work, we will focus on the cost x-efficiency and the profit x-efficiency that their translog functions come as follows:

$$
\begin{aligned}
& \text { Ln TC }=\alpha_{0}+\frac{1}{2} \sum_{i=1}^{2} \beta_{\mathrm{i}} \operatorname{Lny}_{\mathrm{i}}+\frac{1}{2} \sum_{i=1}^{2} \sum_{j=1}^{2} \quad \beta_{\mathrm{ij}} \operatorname{Lny}_{\mathrm{i}} \operatorname{Lny}_{\mathrm{j}}+\sum_{k=1}^{3} \gamma_{\mathrm{k}} \operatorname{Lnp}_{\mathrm{k}} \\
& +\frac{1}{2} \sum_{l=1}^{3} \sum_{m=1}^{3} \gamma_{\mathrm{lm}} \operatorname{Ln} \mathrm{p}_{\mathrm{l}} \operatorname{Lnp}_{\mathrm{m}}+\sum_{i=1}^{2} \sum_{k=1}^{3} \zeta_{\text {ik }} \text { Lny }_{\mathrm{i}} \text { Lnp }_{\mathrm{k}}+\varepsilon \\
& \operatorname{Ln}(\pi+a)=\alpha_{0}+\frac{1}{2} \sum_{i=1}^{2} \beta_{\mathrm{i}} \operatorname{Lny}_{\mathrm{i}}+\frac{1}{2} \quad \sum_{i=1}^{2} \sum_{j=1}^{2} \quad \beta_{\mathrm{ij}} \operatorname{Lny}_{\mathrm{i}} \operatorname{Lny}_{\mathrm{j}}+\sum_{k=1}^{3} \gamma_{\mathrm{k}} \operatorname{Lnp}_{\mathrm{k}} \\
& +\frac{1}{2} \sum_{l=1}^{3} \sum_{m=1}^{3} \gamma_{\mathrm{lm}} \operatorname{Ln} \mathrm{p}_{\mathrm{l}} \operatorname{Lnp}_{\mathrm{m}}+\sum_{i=1}^{2} \sum_{k=1}^{3} \zeta_{\mathrm{ik}} \text { Lny }_{\mathrm{i}} \operatorname{Lnp}_{\mathrm{k}}+\varepsilon_{\pi \mathrm{b}}
\end{aligned}
$$

\subsection{Definition of Variables}

The tables below summarize the measures of the different variables included in our study.

Table 1. Definitions of the variables of the SFA method

\begin{tabular}{ll}
\hline variables & Definitions \\
\hline Cost & Total interest and non-interest \\
\hline Net income & Total income - total cost - tax \\
\hline Labor price & Total staff costs / number of employees \\
\hline Price of capital & Capital expenditure / value of fixed assets \\
\hline Fund prices & Interest Expense / Deposit \\
\hline Total loan & Short-term, medium-term and long-term loans. \\
\hline $\begin{array}{l}\text { Other productive } \\
\text { assets }\end{array}$ & $\begin{array}{l}\text { Sum of invested values }+ \text { interbank funds (gain) }+ \text { loans to special } \\
\text { sectors (directed loan) }\end{array}$ \\
\hline
\end{tabular}




\section{1) Macrothink \\ International Journal of Accounting and Financial Reporting

Table 2. Definitions of DEA method variables

\begin{tabular}{|c|c|c|c|}
\hline \multicolumn{2}{|l|}{ Variables } & \multicolumn{2}{|l|}{ Definitions } \\
\hline \multicolumn{2}{|c|}{ Net income } & \multicolumn{2}{|l|}{ Total income - total cost - tax } \\
\hline \multicolumn{2}{|c|}{$\begin{array}{l}\text { Other productive } \\
\text { assets }\end{array}$} & \multicolumn{2}{|c|}{$\begin{array}{l}\text { Sum of invested values }+ \text { interbank funds (gain) }+ \text { loans to special } \\
\text { sectors (directed loan) }\end{array}$} \\
\hline \multicolumn{2}{|l|}{ Loan } & \multicolumn{2}{|c|}{ Short-term, medium-term and long-term loans. } \\
\hline \multicolumn{2}{|l|}{ Cost } & \multicolumn{2}{|l|}{ Total interest and non-interest } \\
\hline \multicolumn{2}{|l|}{ Staff } & \multicolumn{2}{|l|}{ Number of employees } \\
\hline \multicolumn{2}{|c|}{ Fixed capital } & \multicolumn{2}{|l|}{ Value of fixed assets } \\
\hline \multicolumn{2}{|l|}{ Deposit } & \multicolumn{2}{|c|}{ Short-term, medium-term and long-term Deposit } \\
\hline \multicolumn{2}{|c|}{ Labor price } & \multicolumn{2}{|c|}{ Total staff costs / number of employees } \\
\hline \multicolumn{2}{|c|}{ Price of capital } & \multicolumn{2}{|c|}{ Capital expenditure / value of fixed assets } \\
\hline \multicolumn{2}{|c|}{ Fund prices } & \multicolumn{2}{|l|}{ Interest Expense / Deposit } \\
\hline \multicolumn{4}{|c|}{$\begin{array}{l}\text { Indeed, our study is composed of two levels. In the first level, we will be interested in the } \\
\text { efficiency and the x-efficiency of the Islamic and conventional banks constituting our sample } \\
\text { then we will be interested in their stability. The table below summarizes the measures of the } \\
\text { different variables included in our model studying the stability of Islamic and conventional } \\
\text { banks. }\end{array}$} \\
\hline \multicolumn{4}{|c|}{ Table 3. Definitions of Z-Score variables } \\
\hline Variables & \multicolumn{2}{|c|}{ Definitions } & Definitions \\
\hline $\mathbf{C E}$ & \multicolumn{2}{|c|}{ Cost x-efficiency } & Total investment \\
\hline $\mathbf{P E}$ & \multicolumn{2}{|c|}{ profit x-efficiency } & $\begin{array}{l}\text { Market risk: Loss of bank } \mathrm{i} \text { to year } \mathrm{t} \\
\text { on the financial market. }\end{array}$ \\
\hline $\mathbf{T E}$ & \multicolumn{2}{|c|}{ Technical efficiency } & $\begin{array}{l}\text { Credit risk: Loss of bank } i \text { to year } t \text { in } \\
\text { terms of credit. }\end{array}$ \\
\hline ROE & \multicolumn{2}{|c|}{$\begin{array}{l}\text { Return on equity }=\text { Net } \mathbf{O P} \\
\text { income } / \text { total equity }\end{array}$} & $\begin{array}{l}\text { Operational risk: Operational loss of } \\
\text { bank i to year } \mathrm{t} \text {. }\end{array}$ \\
\hline SR & \multicolumn{2}{|c|}{$\begin{array}{l}\text { Solvability ratio }=\text { Total debt } / \text { TA } \\
\text { equity }\end{array}$} & Total assets \\
\hline CTI & \multicolumn{3}{|c|}{$\begin{array}{l}\text { Cost to income ratio }=\text { Total } \mathbf{I N F} \quad \text { Inflation } \\
\text { cost } / \text { Net income }\end{array}$} \\
\hline
\end{tabular}




\subsection{The Sample}

The sample is composed of 40 banks (20 Islamic banks and 20 conventional banks) over the 2004-2014 period. The banks are distributed as follows:

\begin{tabular}{ll}
\hline Continent & banks \\
\hline America & 8 \\
\hline Europe & 11 \\
\hline Asia & 20 \\
\hline Australia & 1 \\
\hline
\end{tabular}

The choice of these banks is justified by their contribution to the total assets of both types of finance and the availability of their financial losses. This selection method allowed us to have a global idea on the effectiveness, efficiency, risk and stability of the two banking sectors. These institutions were selected according to the TOP 1000 WORDS BANKS ranking.

The data was collected from the annual reports of the institutions in question and from the databases bankscope, thomson reuters, riskmetrics and orex database.

\section{Results and Interpretations}

\subsection{X-Efficiency of Islamic and Conventional Banks}

The purpose of this section is to present the empirical results of our cost and profit $\mathrm{X}$-efficiency study, of Islamic banks and conventional banks, and to compare them.

Table 4. Cost X-efficiency of Islamic and conventional banks (by DMU)

\begin{tabular}{lllc}
\hline Conventional banks & Scores & Islamic banks & Scores \\
\hline JP Morgan Chase \& Co & $81,59 \%$ & ABC islamic bank & $84,27 \%$ \\
\hline UBS & $81,02 \%$ & Abu Dhabi Islamic Bank & $83,61 \%$ \\
\hline ABN AMRO Bank & $83,80 \%$ & Al baraka bq & $83,70 \%$ \\
\hline Deutsche Bank AG & $79,44 \%$ & Asya Finans Kurumu & $84,02 \%$ \\
\hline Lloyds TSB Group & $81,62 \%$ & Bank Islam Malaysia Berhad & $84,29 \%$ \\
\hline Credit Suisse Group & $81,78 \%$ & Bank islami & $85,74 \%$ \\
\hline
\end{tabular}




\section{MlMacrothink}

Norinchukin Bank

\section{2,11\% Bank Muamalat Malaysia 83,94\%}

Berhad

\begin{tabular}{|c|c|c|c|}
\hline Nordea Group & $83,42 \%$ & Bank Sepah & $80,76 \%$ \\
\hline Scotiabank & $81,68 \%$ & Cap invet & $84,64 \%$ \\
\hline Royal Bank of Canada & $80,60 \%$ & Commercial bank & $84,30 \%$ \\
\hline Bayerische Landesbank & $85,38 \%$ & Dubai islamic bank & $83,08 \%$ \\
\hline DZ Bank Deutsche Zentral & $83,70 \%$ & Emirates Islamic Bank & $85,08 \%$ \\
\hline Danske Bank & $83,60 \%$ & Itmarr bank & $83,88 \%$ \\
\hline Bank of Montreal & $82,79 \%$ & Karafarin Bank & $86,39 \%$ \\
\hline Toronto-Dominion Bank & $81,70 \%$ & Kuwait Finance House & $83,75 \%$ \\
\hline Canadian Imperial Bank of Commerce & $82,61 \%$ & Meezan bank & $84,18 \%$ \\
\hline Allied Irish Banks & $84,62 \%$ & $\begin{array}{l}\text { Samba bank, amercan saudian } \\
\text { bank }\end{array}$ & $81,99 \%$ \\
\hline Westpac Banking Corporation & $83,47 \%$ & The International Investor & $81,95 \%$ \\
\hline SunTrust Banks & $84,99 \%$ & RHB Islamic Bank Berhad & $84,19 \%$ \\
\hline Wells Fargo \& Co, & $84,14 \%$ & PT Bank Syariah Mandiri & $85,69 \%$ \\
\hline Average & $82,70 \%$ & Average & $83,97 \%$ \\
\hline $\begin{array}{l}\text { Ho: score } \mathrm{BC} \\
\text { BI }\end{array}$ & $=$ score & $\mathbf{z}=-2.277$ & $=0.0228$ \\
\hline
\end{tabular}

Student's test

Ho: $\operatorname{mean}($ diff $)$
$=0$

Ha: $\operatorname{mean}($ diff $)<$ Ha:

0

$\operatorname{Pr}(\mathrm{T}<\mathrm{t})=\underset{0.0215}{0.0107}=\underset{0.9893}{\operatorname{Pr}(|\mathrm{T}|}>|\mathrm{t}|)=\operatorname{Pr}(\mathrm{T}>\mathrm{t})=$
0




\section{Macrothink \\ International Journal of Accounting and Financial Reporting ISSN 2162-3082 2020, Vol. 10, No. 1}

Table 5. X-efficiency cost of Islamic and conventional banks (per year)

\begin{tabular}{lll}
\hline & Conventional Banks & Islamic Banks \\
\hline 2004 & $83,04 \%$ & $84,56 \%$ \\
\hline 2005 & $82,74 \%$ & $84,56 \%$ \\
\hline 2006 & $82,63 \%$ & $84,33 \%$ \\
\hline 2008 & $82,33 \%$ & $83,95 \%$ \\
\hline 2009 & $82,37 \%$ & $83,99 \%$ \\
\hline 2010 & $82,46 \%$ & $83,94 \%$ \\
\hline 2011 & $82,67 \%$ & $83,81 \%$ \\
\hline 2012 & $82,90 \%$ & $83,76 \%$ \\
\hline 2013 & $82,91 \%$ & $83,71 \%$ \\
\hline 2014 & $82,81 \%$ & $83,47 \%$ \\
\hline average & $82,86 \%$ & $83,61 \%$ \\
\hline
\end{tabular}

Wilcoxon test

Ho: score $\mathrm{BC}=$ score $\mathbf{z}=-2.936$

BI

$\operatorname{Prob}>|\mathbf{z}|=0.0033$

Student's test

Ho: mean $($ diff $)=0$

Ha: mean(diff) $<0$

$\operatorname{Pr}(\mathrm{T}<\mathrm{t})=0.0000$

Ha: mean(diff) $!=0$

$\operatorname{Pr}(|\mathrm{T}|>|\mathrm{t}|)=0.0000$

Ha: $\operatorname{mean}($ diff $)>0$

$\operatorname{Pr}(\mathrm{T}>\mathrm{t})=1.0000$ 


\section{MlMacrothink}

International Journal of Accounting and Financial Reporting ISSN 2162-3082 2020, Vol. 10, No. 1

A bank is said to be totally effective, in terms of costs, if it uses the minimum of inputs to produce outputs. As a result, the score or level of cost x-efficiency can be defined as the deviation from the minimum cost. On this basis and using the SFA method, we concluded that Islamic banks are more effective than conventional banks. In 2007, 82.5\% of banks in our sample were impacted by the credit subprime. During the crisis, $85 \%$ of Islamic banks ( $80 \%$ of conventional banks) experienced a drop in effectiveness due to their intervention in international raw material and currency markets. In 2011, however, only Islamic banks were impacted by the revolutions of Arab countries and the x-efficiency score rose from $83.81 \%$ in 2010 to $83.47 \%$ in 2013 .

In addition, the review of Tables 4 and 5 show us that Islamic banks admit an average score of cost x-efficiency of $83.97 \%$ against $82.7 \%$ for conventional banks. The most effective banks are Karafarin Bank and Bayerische Landesbank while the least effective banks are Bank Sepah and Deutsche Bank AG. The results of Deutsche Bank AG can be explained by the credibility shocks of its leaders (Note 2), its deficit of $\$ 5.741$ billion and the repayment of $\$ 12$ billion in 2008 to American international group that have heavily affected during the crisis. Bank Sepah, on the other hand, is a national bank known for its financing of the projects of the Iranian army, it is thus the martyr of the sociopolitical problems of the Iranian state as for the production of the nuclear power.

By and large, examining the cost x-efficiency has shown that Islamic banks are more effective than conventional banks. In contrast, conventional banks are more effective in terms of profit (Rozzani, R., and Abdul Rahman, R. (2013) and Al-Habshi, M. S., and al. (2006)]. Likewise, the review of profit efficiency resulted in a score of $90.95 \%$ and $94.72 \%$ for the benefit of Islamic banks as shown in the following table:

Table 6. Profit X-efficiency of Islamic and conventional banks (by DMU)

\begin{tabular}{lllc}
\hline Conventional banks & Scores & Islamic banks & Scores \\
\hline JP Morgan Chase \& Co & $89.91 \%$ & ABC islamic bank & $96.21 \%$ \\
\hline UBS & $91.33 \%$ & Abu Dhabi Islamic Bank & $96.43 \%$ \\
\hline ABN AMRO Bank & $90.73 \%$ & Al baraka Bank & $96.40 \%$ \\
\hline Deutsche Bank AG & $90.93 \%$ & Asya Finans Kurumu & $96.24 \%$ \\
\hline Lloyds TSB Group & $91.36 \%$ & Bank Islam Malaysia Berhad & $96.92 \%$ \\
\hline Credit Suisse Group & $91.39 \%$ & Bank islami & $95.97 \%$ \\
\hline Norinchukin Bank & $90.93 \%$ & Bank Muamalat Malaysia Berhad & $95.63 \%$ \\
\hline
\end{tabular}




\begin{tabular}{|c|c|c|c|}
\hline Nordea Group & $91.47 \%$ & Bank Sepah & $94.87 \%$ \\
\hline Scotiabank & $90.67 \%$ & Cap invet & $96.29 \%$ \\
\hline Royal Bank of Canada & $90.70 \%$ & Commercial bank & $96.82 \%$ \\
\hline Bayerische Landesbank & $91.30 \%$ & Dubai islamic bank & $90.98 \%$ \\
\hline DZ Bank Deutsche Zentral & $90.82 \%$ & Emirates Islamic Bank & $97.00 \%$ \\
\hline Danske Bank & $89.29 \%$ & Itmarr bank & $94.55 \%$ \\
\hline Bank of Montreal & $91.27 \%$ & Karafarin Bank & $95.63 \%$ \\
\hline Toronto-Dominion Bank & $90.58 \%$ & Kuwait Finance House & $90.01 \%$ \\
\hline $\begin{array}{l}\text { Canadian Imperial Bank of } \\
\text { Commerce }\end{array}$ & $91.16 \%$ & Meezan bank & $95.98 \%$ \\
\hline Allied Irish Banks & $91.16 \%$ & Samba bank. amercan saudian bank & $97.22 \%$ \\
\hline Westpac Banking Corporation & $90.99 \%$ & The International Investor & $82.42 \%$ \\
\hline SunTrust Banks & $91.74 \%$ & RHB Islamic Bank Berhad & $92.21 \%$ \\
\hline Wells Fargo \& Co. & $91.37 \%$ & PT Bank Syariah Mandiri & $96.56 \%$ \\
\hline Average & $90.95 \%$ & Average & $94.72 \%$ \\
\hline
\end{tabular}

Wilcoxon test

Ho: score $\mathrm{BC}=$ score $\mathbf{z}=-3.024$

$\operatorname{Prob}>|\mathbf{z}|=0.0025$ $\mathrm{BI}$

Student's test

$$
\begin{aligned}
& \text { Ho: } \\
& =0
\end{aligned}
$$

Ha: mean(diff) < Ha:

0

$$
\operatorname{Pr}(\mathrm{T}<\mathrm{t})=0.0001
$$
mean(diff) $!=0$ Ha: mean (diff) $>$ $\operatorname{Pr}(|\mathrm{T}|>|\mathrm{t}|)=\operatorname{Pr}($ 0.0002 0 0.9999 
Table 7. Profit X-efficiency of Islamic and conventional banks (per year)

\section{Conventional banks}

\begin{tabular}{lll}
\hline 2004 & $90,96 \%$ & $96,12 \%$ \\
\hline 2005 & $90,83 \%$ & $95,88 \%$ \\
\hline 2006 & $90,69 \%$ & $95,52 \%$ \\
\hline 2007 & $90,81 \%$ & $94,51 \%$ \\
\hline 2008 & $91,43 \%$ & $94,19 \%$ \\
\hline 2009 & $91,27 \%$ & $95,36 \%$ \\
\hline 2010 & $91,20 \%$ & $95,47 \%$ \\
\hline 2011 & $90,93 \%$ & $95,62 \%$ \\
\hline 2012 & $90,84 \%$ & $93,18 \%$ \\
\hline 2013 & $90,83 \%$ & $93,30 \%$ \\
\hline
\end{tabular}

$\begin{array}{ll}\text { Average } \quad 90,95 \% & 94,72 \%\end{array}$

Wilcoxon Ho: score BC $=$ score BI test

$\mathbf{z}=-2.934$

$\operatorname{Prob}>|\mathbf{z}|=0.0033$

Student's Ho: mean $($ diff $)=0$

Ha: mean (diff) $<0$

test

\section{Islamic banks}

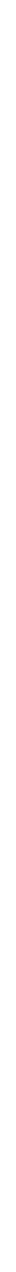




\section{Ml Macrothink}

International Journal of Accounting and Financial Reporting ISSN 2162-3082 2020, Vol. 10, No. 1

Islamic banks are more efficient in terms of profit than conventional banks. These results are consistent with the theory because if we look at the structure of the portfolios of Islamic banks, we see that they manage the funds of the oil companies. Thus, they engage more than conventional banks in commercial, industrial and agricultural transactions and they have a prominent access to liquidity following the prohibition of hoarding by Islamic doctrine.

As in Tables 6 and 7, we note that the most efficient banks are Samba Bank and SunTrust Bank. SunTrust Bank is the result of the merger of Trust Company and SunBank. It acquires several banks in Europe and America to have more than 1700 agencies in the world. Its client portfolio and the diversity of its products have made it a strong bank in the face of the crisis and its profitability score increased from $91.09 \%$ in 2007 to $93.98 \%$ in 2009. Moreover, Samba bank was able to use technology to improve its services and be closer to its customers by offering more services that meet their needs. Unlike SunTrust Bank, samba bank was hit by the credit subprime and its profitability score dropped by $0.2 \%$ in 2009 due to its financing and investment in oil, mining and real estate activities. Similarly, the level of effectiveness decreased in 2011, 2012 and 2013. It went from $95.62 \%$ to $92.72 \%$ due to the decline in activity of Islamic banks during the period of the Arab revolutions. In contrast, conventional banks have been more resilient to the credit subprime, only $60 \%$ were impacted by the collapse of real-estate funds.

In summary, Islamic banks are more effective than conventional banks and their ability to invest in times of low market liquidity has thwarted the adverse effects of financial shocks.

\subsection{Efficiency of Islamic and Conventional Banks}

Table 8. Efficiency of Islamic and conventional banks (by DMU)

\begin{tabular}{lllc}
\hline Conventional banks & Scores & Islamic banks & Scores \\
\hline JP Morgan Chase \& Co & $100,00 \%$ & ABC islamic bank & $93,97 \%$ \\
\hline UBS & $69,91 \%$ & Abu Dhabi Islamic Bank & $71,85 \%$ \\
\hline ABN AMRO Bank & $99,92 \%$ & al baraka bank & $74,18 \%$ \\
\hline Deutsche Bank AG & $11,95 \%$ & Asya Finans Kurumu & $95,54 \%$ \\
\hline Lloyds TSB Group & $86,27 \%$ & Bank Islam Malaysia Berhad & $57,31 \%$ \\
\hline The Credit Suisse Group & $94,28 \%$ & Bank islami & $39,63 \%$ \\
\hline Norinchukin Bank & $97,87 \%$ & Bank & Muamalat \\
\hline Nordea Group & & Berhad & $57,33 \%$ \\
\hline
\end{tabular}


Scotiabank

$69,00 \% \quad$ Cap invet

$90,16 \%$

Royal Bank of Canada

99,96\% Commercial bank

$89,21 \%$

Bayerische Landesbank

$99,31 \% \quad$ Dubai islamic bank

$71,30 \%$

DZ Bank Deutsche Zentral

94,38\% Emirates Islamic Bank

$80,44 \%$

Danske Bank

$86,32 \% \quad$ Itmarr bank

$96,36 \%$

Bank of Montreal

78,65\% Karafarin Bank

$98,85 \%$

Toronto-Dominion Bank

80,16\% Kuwait Finance House

$94,90 \%$

Canadian Imperial Bank of 46,61\% Meezan bank

$36,17 \%$

Commerce

Allied Irish Banks

$17,91 \%$

Samba bank. amercan saudian 28,08\% bank

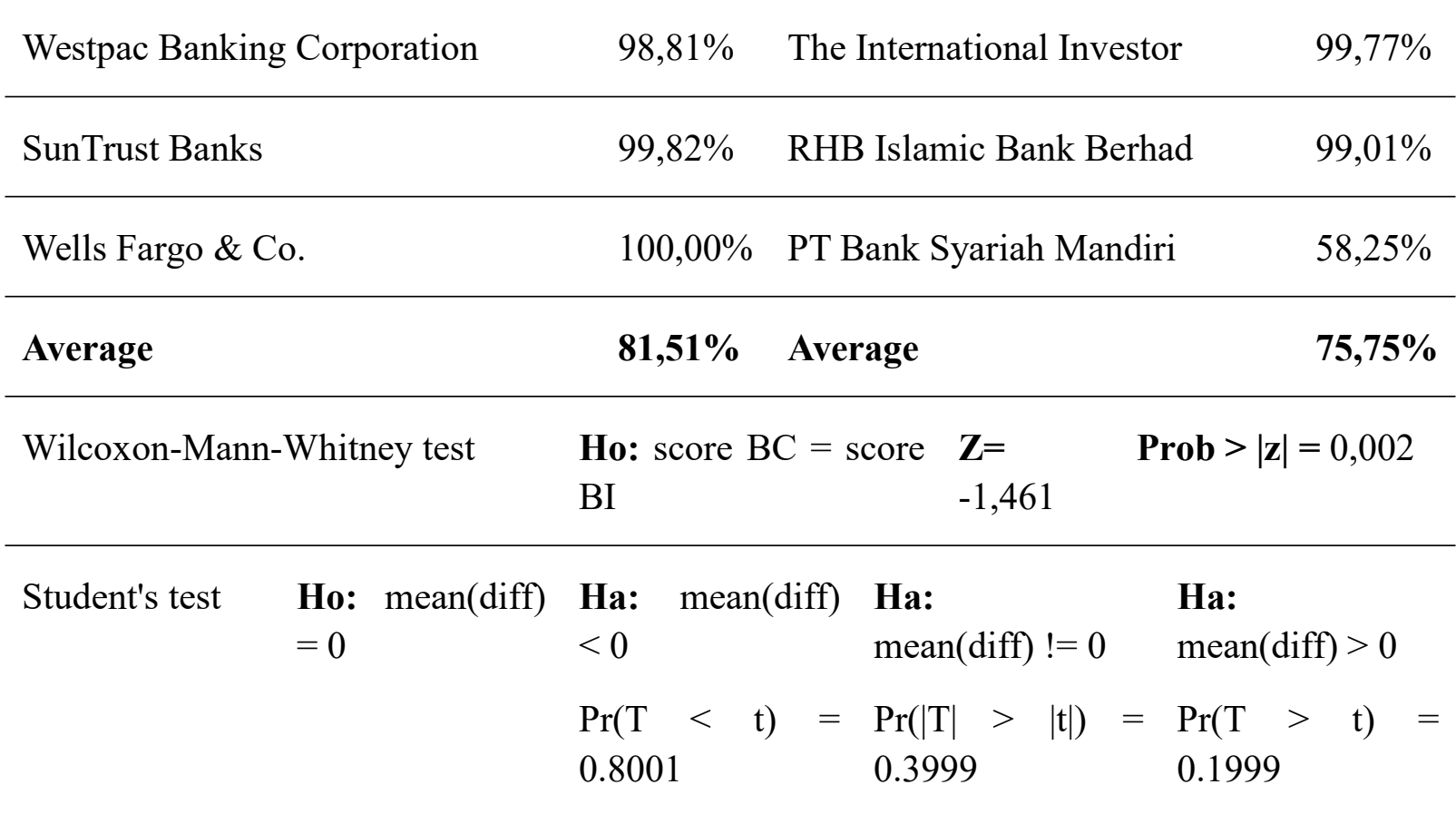




\section{Macrothink \\ International Journal of Accounting and Financial Reporting ISSN 2162-3082 2020, Vol. 10, No. 1}

Table 9. Efficiency of Islamic and conventional banks (per year)

\begin{tabular}{lll}
\hline & Conventional banks & Islamic banks \\
\hline 2004 & $80,91 \%$ & $77,85 \%$ \\
\hline 2005 & $78,67 \%$ & $77,07 \%$ \\
\hline 2006 & $79,00 \%$ & $72,39 \%$ \\
\hline 2007 & $75,20 \%$ & $70,28 \%$ \\
\hline 2008 & $75,79 \%$ & $74,92 \%$ \\
\hline 2009 & $81,18 \%$ & $73,01 \%$ \\
\hline 2010 & $85,51 \%$ & $74,48 \%$ \\
\hline 2011 & $82,27 \%$ & $76,73 \%$ \\
\hline 2012 & $84,57 \%$ & $76,65 \%$ \\
\hline 2013 & $85,27 \%$ & $78,86 \%$ \\
\hline 2014 & $88,23 \%$ & $81,03 \%$ \\
\hline Average & $\mathbf{8 1 , 5 1 \%}$ & \\
\hline
\end{tabular}

Wilcoxon-Mann-Whitney test

Student's test
Ho: score $\mathrm{BC}=$ score $\mathrm{BI}$

$$
\operatorname{Prob}>|\mathbf{z}|=0,000
$$

Ha: mean(diff $)<0$

$\operatorname{Pr}(\mathrm{T}<\mathrm{t})=1.0000$

Ha: mean(diff) $!=0$

$\operatorname{Pr}(|\mathrm{T}|>|\mathrm{t}|)=0.0001$

Ha: mean(diff $)>0$

$\operatorname{Pr}(\mathrm{T}>\mathrm{t})=0.0000$

The table above shows that JP Morgan Chase \& Co and Wells Fargo \& Co. are on the 
efficiency curve, their respective scores being one unit for the entire study period. For Islamic banks the best bank is The International Investor, it is efficient at $99.77 \%$ on average and its score was one unit over the entire study period except for the year 2009 for which its level of efficiency dropped by $2.5 \%$. This study proves that Islamic banks are less efficient than conventional banks in the crisis period. If we admit that Islamic banks are riskier than conventional banks because of the principle of sharing profits and losses and that their efficiency score have fallen by just $2.11 \%$ in 2007 and $1.91 \%$ in 2009 , we can conclude that they were able to resist the credit subprime. However, the efficiency score of conventional banks went from $79.00 \%$ in 2006 to $75.20 \%$ in 2007 because of the colossal losses they experienced in September 2007. Therefore, we can say that Islamic banks were more resilient to the crisis. Moreover, an economic slowdown took place in 2011 in the Arab countries caused by several popular uprisings. This slowdown was combined with a $0.8 \%$ efficiency loss for Islamic banks, which once again confirms the capacity of the Islamic financial system to absorb financial shocks.

\subsection{Stability of Islamic and Conventional Banks}

Table 10. Descriptive statistics of Islamic banks

\begin{tabular}{llllll}
\hline Variable & Obs & Mean & Std. Dev. & Min & Max \\
\hline te & 220 & .7574818 & .2917781 & .064 & 1 \\
\hline ce & 220 & .8397251 & .0153134 & .7921316 & .8855448 \\
\hline pe & 220 & .9471612 & .0474146 & .6277689 & .9961287 \\
\hline roe & 220 & .5453356 & .5650928 & -1.61824 & 3.835952 \\
\hline cti & 220 & 8.859377 & 7.34729 & .0115735 & 43.94091 \\
\hline cr & 220 & .8785592 & 1.570505 & -.2192308 & 9.943398 \\
\hline mr & 220 & .7056769 & 1.081402 & .0023248 & 5.936133 \\
\hline or & 220 & .3485292 & .5635342 & .0000969 & 2.983652 \\
\hline ta & 220 & .4411995 & .6969371 & .000364 & 4.535518 \\
\hline ti & 220 & 27.83311 & 81.48175 & .0192465 & 6855.0742 \\
\hline inf & 220 & 5.288762 & 20.03519 & .007046 & 204.6 \\
\hline & 220 & 6.491364 & 6.63216 & -4.9 & 39.3 \\
\hline
\end{tabular}


Table 11. Descriptive statistics of conventional banks

\begin{tabular}{llllll}
\hline Variable & Obs & Mean & Std. Dev. & Min & Max \\
\hline te & 220 & .8150636 & .2864535 & .053 & 1 \\
\hline pe & 220 & .827023 & .0165331 & .7793928 & .8621495 \\
\hline roe & 220 & .9095467 & .0082523 & .8771495 & .951679 \\
\hline sr & 220 & .1763782 & .3456185 & -2.796392 & 1.298914 \\
\hline cti & 220 & 3.680799 & 4.632431 & .0009374 & 38.68899 \\
\hline cr & 220 & 1.451467 & 4.181926 & -15.46484 & 36.08989 \\
\hline mr & 220 & 15.33119 & 15.2478 & .09209 & 73.13505 \\
\hline or & 220 & 13.19743 & 19.55376 & .165 & 143.76 \\
\hline ta & 220 & 20.88458 & 29.4385 & .1241291 & 198.45 \\
\hline inf & 220 & 475.3809 & 491.2085 & 27.8764 & 2573 \\
\hline & 220 & 1.77 & 1.190031 & -4.5 & 4.9 \\
\hline
\end{tabular}

In support of Tables 10 and 11 we noted the effect of multiple financial shocks on conventional banks. These have caused significant losses in terms of income and productivity and rapid growth in the cost-to-income ratio. The imperfections of conventional finance have been accompanied by the emergence of Islamic finance characterized by its rapid development. In fact, Islamic banks are three times more profitable than conventional banks and more efficient in terms of profit and cost. This seems logical because Islamic banks invest more than $20 \%$ of their assets, on average, that is to say they invest five times more than conventional banks. In addition, Islamic banks are riskier than conventional banks. On average, they lose $5.795 \%$ and $3.9413 \%$ of their assets, respectively, in the form of credit risk and operational risk. This is consistent with the results of the work of Abd Elrahman Elzahi Saaid Ali (2011) in which he confirmed that Islamic banks admitted a greater credit risk than conventional banks and this because of their ethical nature that presumes the sharing of profits and losses. On the other hand, Burchan Sakarya (2016) has noted the existence of an outstanding performance of Islamic banks throughout the study period and a reduced level of risk in comparison with conventional banks. Similarly, the studies of Rajhi, W., and Hassairi, 
S. A., (2013), Abd Elrahman Elzahi Saaid Ali (2011) resulted in a limited risk for Islamic banks.

Notwithstanding, Islamic banks are less risky than conventional banks, in terms of market risk, and lose $3.214 \%$ of their assets against $4.119 \%$ for conventional banks. By cons, Pejman, A., Philip, M., \& Tarazi, A. (2011) stated that there was no significant difference between Islamic banks and conventional banks from a market risk point of view.

As a result, we can say that Islamic banks are riskier than conventional banks and their losses exceed those of conventional banks despite the difference in size.

Nevertheless, Islamic banks are more stable than conventional banks despite their large size and low level of risk. On average, conventional banks are 7 times larger than Islamic banks. This is reflected by an average rate of stability of $97.47 \%$ for Islamic banks versus $81.69 \%$ for conventional banks as presented in the following tables.

Table 12. Stability of Islamic and conventional banks (By DMU)

\begin{tabular}{|c|c|c|c|}
\hline Islamic Banks & Scores & Conventional Banks & Scores \\
\hline $\mathrm{ABC}$ islamic bank & $98,9863 \%$ & JP Morgan Chase \& Co & $75,7674 \%$ \\
\hline Abu Dhabi Islamic Bank & $97,2363 \%$ & UBS & $74,4267 \%$ \\
\hline Al baraka bank & $92,5302 \%$ & ABN AMRO Bank & $66,4223 \%$ \\
\hline Asya Finans Kurumu & $98,6924 \%$ & Deutsche Bank AG & $87,7246 \%$ \\
\hline Bank Islam Malaysia Berhad & $99,7016 \%$ & Lloyds TSB Group & $78,3633 \%$ \\
\hline Bank islami & $98,1134 \%$ & The Credit Suisse Group & $98,8807 \%$ \\
\hline Bank Muamalat Malaysia Berhad & $98,9217 \%$ & Norinchukin Bank & $88,1364 \%$ \\
\hline Bank Sepah & $98,8755 \%$ & Nordea Group & $98,5465 \%$ \\
\hline Cap invet & $99,2630 \%$ & Scotiabank & $93,1413 \%$ \\
\hline Commercial bank & $99,7561 \%$ & Royal Bank of Canada & $64,9166 \%$ \\
\hline Dubai islamic bank & $91,8814 \%$ & Bayerische Landesbank & $58,4415 \%$ \\
\hline Emirates Islamic Bank & $97,4906 \%$ & DZ Bank Deutsche Zentral & $91,3537 \%$ \\
\hline
\end{tabular}


Itmarr bank

98,1501\% Danske Bank

$92,1406 \%$

\begin{tabular}{llll}
\hline Karafarin Bank & $98,9123 \%$ & Bank of Montreal & $94,1384 \%$ \\
\hline Kuwait Finance House & $99,8165 \%$ & Toronto-Dominion Bank & $80,3610 \%$ \\
\hline Meezan bank & $98,2929 \%$ & $\begin{array}{l}\text { Canadian Imperial Bank of } \\
\text { Commerce }\end{array}$ & $95,9623 \%$ \\
\hline
\end{tabular}

Samba bank, amercan saudian 96,1700\% Allied Irish Banks

$62,9333 \%$ bank

The International Investor

$$
99,2146 \%
$$

Westpac

Banking $\quad 67,9376 \%$

Corporation

\begin{tabular}{llll}
\hline RHB Islamic Bank Berhad & $87,8430 \%$ & SunTrust Banks & $64,7260 \%$ \\
\hline PT Bank Syariah Mandiri & $99,5266 \%$ & Wells Fargo \& Co. & $99,4106 \%$ \\
\hline Average & $\begin{array}{l}\mathbf{9 7 , 4 6 8 7} \\
\mathbf{\%}\end{array}$ & Average & $\mathbf{8 1 , 6 8 6 5 \%}$ \\
\hline
\end{tabular}

Wilcoxon test

Ho: score $\mathrm{BC}=$ score $\mathrm{BI}$

$$
\mathbf{z}=3.808
$$

$\operatorname{Prob}>|\mathbf{z}|=0.0001$

\begin{tabular}{|c|c|}
\hline $\begin{array}{l}\text { Ha: } \\
\text { mean(diff) } !=0\end{array}$ & $\begin{array}{l}\text { Ha: } \\
\text { mean }(\text { diff })>0\end{array}$ \\
\hline $\begin{array}{l}\mathrm{r}(|\mathrm{T}|>|\mathrm{t}|)= \\
0000\end{array}$ & $\begin{array}{l}\operatorname{Pr}(T>t) \\
0.0000\end{array}$ \\
\hline
\end{tabular}

Student's test Ho: mean(diff) Ha: mean(diff $)<0$

Table 13. Stability of Islamic and conventional banks (Per year)

\begin{tabular}{lll}
\hline & Islamic banks & Conventional banks \\
\hline $\mathbf{2 0 0 4}$ & $96,2362 \%$ & $85,8388 \%$ \\
\hline $\mathbf{2 0 0 5}$ & $96,1909 \%$ & $84,3401 \%$ \\
\hline $\mathbf{2 0 0 6}$ & $97,0209 \%$ & $82,5421 \%$ \\
\hline $\mathbf{2 0 0 7}$ & $98,0487 \%$ & $80,5122 \%$ \\
\hline
\end{tabular}




\begin{tabular}{lll}
$\mathbf{2 0 0 8}$ & $98,1712 \%$ & $82,0199 \%$ \\
\hline $\mathbf{2 0 0 9}$ & $98,7441 \%$ & $80,8555 \%$ \\
\hline $\mathbf{2 0 1 0}$ & $97,4586 \%$ & $80,2521 \%$ \\
\hline $\mathbf{2 0 1 1}$ & $98,0091 \%$ & $82,4967 \%$ \\
\hline $\mathbf{2 0 1 2}$ & $97,4480 \%$ & $80,6397 \%$ \\
\hline $\mathbf{2 0 1 3}$ & $97,5592 \%$ & $79,9503 \%$ \\
\hline $\mathbf{2 0 1 4}$ & $97,2691 \%$ & $79,1045 \%$ \\
\hline Average & $\mathbf{9 7 , 4 6 8 7 \%}$ & $\mathbf{8 1 , 6 8 6 5 \%}$ \\
\hline
\end{tabular}

Wilcoxon test Ho: score BI $=$ score BC $\quad \mathbf{z}=2.934$

$\operatorname{Prob}>|\mathbf{z}|=0.0033$

\begin{tabular}{lll}
\hline Student's test $\quad$ Ho: mean $($ diff $)=0 \quad$ Ha: mean $($ diff $)<0$ \\
& $\operatorname{Pr}(\mathrm{T}<\mathrm{t})=1.0000$
\end{tabular}

Ha: mean(diff) $!=0$

$\operatorname{Pr}(|\mathrm{T}|>|\mathrm{t}|)=0.0000$

Ha: mean (diff) $>0$

$\operatorname{Pr}(\mathrm{T}>\mathrm{t})=0.0000$

During the crisis, the increased volatility of commodity prices, especially oil, created instability in liquidity resources which was reflected in a $1.29 \%$ decline in the stability score. These results are consistent with those of Rahim and Zakaria (2013), Okumus, H. S., and Artar, O. K. (2012), Muhammad, R. and al. (2012), Gamaginta, D., and Rokhim, R. (2011). In view of these studies, Islamic banks are not immune to crises because they have been impacted by the reduction in activity of oil companies and the lack of skills.

However, this instability has not persisted and has resumed its growing trend because of the inherent liquidity of Islamic banks that has played a decisive role in the insurance of investments and Shariaa-compatible operations. This confirms the finding of Sayd, F., Kabir, M. H., and Gregory, C. (2014) stating that the level of participation in the profits and existence of optional reserves are the key factors of financial stability. In addition, Thorsten, B., Asli, D. K., and Ouarda, M. (2010) confirmed that the amount of liquidity held by Islamic 
banks in reserves and their large capitalization made the difference in terms of stability.

Moreover, Islamic banks experienced a period of instability during the Arab revolutions that created a banking panic in multiple countries and the stability score went from $98.01 \%$ in 2011 to $97.269 \%$ in 2014. In the same vein and based on stock market indices, Frankie Chau, Rataporn Deesomsak and Jun Wang (2014), Chesneyet and al. (2011), Jackson (2008) and Lobo (1999) found that Islamic stock prices respond to political changes and collapse in times of turmoil. In other words, the political changes have a negative effect on Shariaa-compatible financial places. These results show that Islamic banks are more stable than conventional banks. Similarly, Siraj, K. K., and Pillai, P. S. (2012), Hasan and Dridi (2010) and Hassan, M. N., and al. (2012) state that sharia-compatible banks admit greater stability than conventional banks. This comes down to the fact that conventional banks have lost value as a result of the increase in their non-performing loan provisioning funds which has allowed Islamic banks to perform better.

\section{Conclusion}

An Islamic bank is a financial institution specializing in lawful business, it shares profits and losses with its customers and proscribes unproductive savings. The literature is rich in comparative studies between Islamic banks and conventional banks that admit socioeconomic and geographical situations similar to the example of the work of Maudos, J., and al. (2002), Bader, M. K., Shamsher, M., and Taufiq, H. (2007), Fadzlan, S., and al. (2009), Abdul Rahman, A. R., and Rosman, R. (2013) and Ali Said (2013).

From a critical point of view, the works exposed previously lack risk and performance indicators or use intangible indicators of risk, efficiency and effectiveness. To decline these limits, we created a score composed of efficiency, effectiveness, profitability, solvency, productivity, investment and risk indicators, as well as macroeconomic indicators. The banks in our sample were selected based on their contribution to the total assets of the both types of finance. This selection method allowed us to have a global idea on the effectiveness, efficiency, risk and stability of the two banking sectors.

This study revealed that Sharia-compatible banks are more effective and less efficient than conventional banks. Thus, although Islamic financial institutions are more risky than conventional financial institutions, Shariaa-compatible banks have a higher level of stability than conventional banks.

Overall, the two types of institutions were able to resist the crisis despite the slight reduction in activity and the minimal decrease in their stability scores due to the decline in activity and the prudent policy they adopted.

However, like all research work, this paper has limitations. Nowadays the concept of banking governance constitutes a means of risk prevention and ensuring banking stability. It is in this area of research that we must reflect in further research.

\section{References}

Abdul Rahman, A. R., \& Rosman, R. (2013). Efficiency of Islamic Banks: A Comparative 
Analysis of MENA and Asian Countries. Journal of Economic Cooperation and Development, 34(1), 63-92.

Ahmad Mokhtar, S. H., Abdullah, N., \& Al-Habshi, M. S. (2006). Efficiency of Islamic banking in Malaysia: A Stochastic Frontier Approach. Journal of Economic Corporation, 37-70.

Aigner, D., Knox Lovell, C. A., \& Schmidit, P. (1977). Formulation and estimation of stochastic frontier production function models. Journal of Econometrics, 21-37.

Akhigbe, A., \& Stevenson, A. B. (2010). Profit efficiency in U.S. BHCs: Effects of increasing non-traditional revenue sources. The Quarterly Review of Economics and Finance, 50, 132-140.

Ali Saaid, A. E. (2011). Islamic banking structures: implications for risk and financial stability. Islamic Economic Studies, 20(2), 50.

Al-Shammari, M., Turen, S., \& Abou El-Seoud, M. S. (2014). Measuring relative efficiency of commercial banks in Bahrain using data envelopment analysis. International Journal of Economics, Finance and Management Sciences, 297-305.

Anwar, S. G., et al. (2013). Economic Freedom, Country Risk and Banking Efficiency: The Case of Potential Gulf Countries Union. Prosiding Persidangan Kebangsaan Ekonomi Malaysia Ke VIII, 1455-1470.

Asli, O. (2013). Integrating analytic network process and data envelopment analysis for efficiency measurement of Turkish commercial banks. Banks and Bank Systems, 8(2), 86-103.

Ayub, M. (2004). Islamic Banking and Finance: Theory and Practice. J.KAU: Islamic Economie, 17(1), 45-49.

Bader, M. K. (2007). Cost, revenue, and profit efficiency of conventional banks: evidence from nineteen developing countries. Capital Markets in Emerging Markets: Malaysia (Chapter 25). McGraw-Hill, Kuala Lumpur.

Bader, M. K., Ariff, M., \& Taufiq, H. (2007, April 1-4). Efficiency of Islamic banks: international evidence. Paper presented in the 14th Annual Global Finance Conference GFC, Melbourne.

Bader, M. K., et al. (2008). Cost, revenue, and profit efficiency of Islamic versus conventional banks: international evidence using financial ratios approach. Review of Islamic Economics, 11(2), 23-76.

Bader, M. K., Shamsher, M., \& Taufiq, H. (2007). Cost, revenue, and profit efficiency of conventional versus Islamic banks: evidence from the Middle East. Islamic Banking and Finance, Kuala Lumpur, 23-25.

Bauer, P., Berger, A., \& Humphrey, D. (1993). Efficiency and productivity growth in U.S. banking. In H. O. Fried, C. A. K. Lovell, \& S. S. Schmidt (Eds.), The measurement of 
productive efficiency: Techniques and applications. Oxford University Press, Oxford.

Benaissa, E. N., Parekh, M. P., \& Wiegand, M. (2005). A Growth model for Islamic banking. The McKinsey Quarterly.

Boumediene, A., \& Caby, J. (2009). The stability of Islamic banks during the subprime crisis.

Bourkhis, K., \& Nabi, S. M. (2010). Have Islamic banks been more resistant than conventional banks to the 2007-2008 financial crisis?. Proceedings Pol. Eco. Dev. Conf., $17(1), 1-26$.

Brown, K. (2003). Islamic Banking Comparative Analysis. The Arab Bank Review, 5(2).

Brown, K., et al. (2007). Efficiency Analysis of Islamic Banks in Africa, Asia and the Middle East. Review of Islamic Economics, 11(2), 5-16.

Bulajić, et al. (2013). A statistical approach to evaluating efficiency of banks. Ekonomska Instravanja-Economic Research, 26(4), 91-100.

Chaffai, E. M., \& Dietsch, M. (1999). Measures of technical efficiency and allocative efficiency by distance functions and application to European banks. Economic Review, 50(3), 633-644.

Charnes, A., Cooper, W. W., \& Rhodes, E. (1978). Measuring the efficiency of decision making units. European Journal of Operational Research, 2, 429-444.

Chesneyet, M., Reshetar, G., \& Karaman, M. (2011). The impact of terrorism on financial markets: An empirical study. Journal of Banking \& Finance, 35, 253-267.

Chortareas, E. G., Girardone, C., \& Ventouri, A. (2011). Bank supervision, regulation, and efficiency: Evidence from the European Union. Journal of Financial Stability.

Cihak, M., \& Hesse, H. (2010). Islamic Banks and Financial Stability: An Empirical Analysis. Journal of Financial Services Research, 38(2), 95-113.

Cochrane, \& Zingales. (2009). Lehman and the Financial Crisis. The Wall Street Journal.

Das, A., \& Ghosh, S. (2006). Financial deregulation and efficiency: An empirical analysis of Indian banks during the post reform period. Review of Financial Economics, 15(3), 193-221.

Das, A., \& Ghosh, S. (2007). Determinants of Credit Risk in Indian State-owned Banks: An Empirical Investigation. MPRA Paper 17301, University Library of Munich, Germany.

Elyes, A. (2014). Performance of the Islamic Market Indexes. The International Journal of Business \& Management, 2(8), 199.

Engle, R. F. (1982). Autoregressive Conditional Heteroscedasticity with Estimates of the Variance of United Kingdom Inflation. Econometrica, 50(4), 987-1007.

Errico, L., \& Farrahbaksh, M. (1998). Islamic banking: Issues in prudential regulation and supervision. IMF Working Paper No. 98/30. 
Fadzlan, S. (2004). The efficiency effects of bank mergers and acquisitions in a developing economy: evidence from Malaysia. International Journal of Applied Econometrics and Quantitative Studies, 1(4), 53-74.

Fadzlan, S., et al. (2009). The Efficiency of Islamic Banks: Empirical Evidence from the MENA and Asian Countries Islamic Banking Sectors. MPRA Paper No. 19072.

Farell, M. J. (1957). The Measurement of Productive Efficiency. Journal of the Royal Statistical Society, Series A, 120, 253-90.

Ferrier, \& Lovell. (1990). Measuring cost efficiency in banking: Econometric and linear programming evidence. Journal of Econometrics, 46(1-2), 229-245.

Firdaus, F., \& Hosen, M. N. (2013). Efficiency of islamic banks using two stage approach of data envelopment analysis. Bulletin of Monetary, Economics and Banking, 16(2), 156-176.

Gamaginta, D., \& Rokhim, R. (2011, December 19-21). The stability comparison between Islamic banks and conventional banks: evidence in Indonesia. Paper presented at the proceedings of the 8th international conference on Islamic economics and finance, Doha, Qatar.

Hasan, \& Dridi. (2010). The Effects of the Global Crisis on Islamic and Conventional Banks: A Comparative Study. IMF Working Paper (pp.1-47).

Hasan, I., \& Morton, K. (2003). Development and efficiency of the banking sector in a transitional economy: Hungarian experience. Journal of Banking \& Finance, 27, 2249-2271.

Hasan, Z. (2005). Evaluation of Islamic Banking Performance: On the Current Use of Econometric Models. MPRA Paper No. 6461 (pp. 1-21).

Hassan, M. K. (2005). The cost, profit and X-efficiency of Islamic banks. Paper presented at 12th Annual Economic Research Forum Conference (pp19-21), Cairo.

Hassan, M. K. (2006). The x-efficiency in Islamic banks. Islamic Economic Studies, 13(2), 49-78.

Hassan, M. K., \& Bashir, A. M. (2003). Determinants of Islamic banking profitability. ERF Paper (pp-1-32).

Hassan, M. K., Samad, M., \& Islam, M. M. (2003). The performance evaluation of the Bahraini banking system. Working paper, University of New Orleans, New Orleans, LA.

Hatem Hatef, A. A., et al. (2013). Testing the Financial Stability of Banks in GCC Countries: Pre and Post Financial Crisis. International Journal of Business and Social Research (IJBSR), 3(4), 93-105.

Heremans, D. (2007). Corporate Governance Issues for Banks: A Financial Stability Perspective (pp.1-28). KUL, Center for Economic Studies.

Hussein, K. A. (2004). Banking efficiency in Bahrain: Islamic versus conventional banks. In Islamic Development Bank, Islamic Research and Training Institute Research Paper 68. 
Islamic Development Bank, Islamic Research and Training Institute, Jeddah.

Imam, P., \& Kpodar, K. (2010). Islamic Banking: How Has it Diffused?. IMF Working Paper 10/195, International Monetary Fund, Washington, D. C.

Iqbal, M. (2001). Islamic and conventional banking in the nineties: a comparative study. Islamic Economic Studies, 8(2), 1-27.

Iqbal, M., Ahmad, A., \& Khan, T. (2007). Challenges to the Islamic banking system. Occasional document number 2 of the Islamic Institute of Research and Training, Islamic Development Bank.

Isik, I., \& Hassan, M. K. (2002a). Technical, scale and allocative efficiencies of Turkish banking industry. Journal of Banking \& Finance, 26, 719-66.

Isik, I., \& Hassan, M. K. (2002b). Cost and profit efficiency of the Turkish banking industry: an empirical investigation. The Financial Review, 37(2), 257-80.

Mabwe, K., \& Robert, W. (2010). A financial Ratio Analysis of Commercial Bank Performance in South Africa. African Review of Economics and Finance, 2(1), 30-53.

Mat Rahim, S. R., \& Zakaria, R. H. (2013). Comparison on stability between Islamic and conventional banks in Malaysia. Journal of Islamic Economics Banking and Finance, 9, 131-149.

Maudos, J., et al. (2002). Cost and profit efficiency in European banks. Journal of International Financial Markets, Institutions and Money, 12, 33-58.

Meeusen, W., \& Van Den Broeck, J. (1977). Efficiency Estimation from Cobb-Douglas Production Functions with Composed Error. International Economic Review, 18(2), 435-444.

Mester, J. L. (1997). Measuring efficiency at U.S. banks: Accounting for heterogeneity is important. European Journal of Operational Research, 98, 230-242.

Mohamad, S., et al. (2007). Cost, Revenue, and Profit Efficiency of Conventional versus Islamic Banks: Financial Ratios Approach. Review of Islamic Economics, 11, 1-54.

Mohamad, S., et al. (2008). Cost, revenue, and profit efficiency of Islamic versus conventional banks: international evidence using data envelopment analysis. Islamic Economic Studies, 15(2), 23-76.

Mohamad, S., Hassan, T., \& Bader, M. K. I. (2008). Efficiency of Conventional versus Islamic Banks: International Evidence using the Stochastic Frontier Approach (SFA). Journal of Islamic Economics, Banking and Finance, 4(2).

Moreno, J., Gallizo, J. L., \& Salvador, M. (2012). Bank ownership and efficiency in the new EU members. Modern Economy (Scientific Research), 68-72.

Muhammad, A. Q., et al. (2012). Efficiency of Islamic and Conventional Banks in Pakistan: A Non-parametric Approach. International Journal of Business and Management, 7(7), 40-50. 
Muhammad, H., et al. (2013). Scale efficiency of Islamic banks of Pakistan. African Journal of Business Management, 7(23), 2249-2256.

Okumus, H. S., \& Artar, O. K. (2012). Islamic banks and financial stability in the GCC: An empirical analysis. Ístanbul Ticaret Üniversitesi Sosyal Bilimler Dergisi, 11(21), 147-164.

Onakoya, A. B., \& Onakoya, A. O. (2013). The performance of conventional and Islamic banks in the United Kingdom: A comparative analysis. Journal of Research in Economics and International Finance, 2, 29-38.

Pastré. O., \& Gecheva, K. (2008). Islamic finance at the crossroads. Financial Economics Review, 197-214.

Pejman, A., Philip, M., \& Tarazi, A. (2011). Risk and Stability in Islamic Banking. HAL, $1-54$.

Pramuka, B. A. (2014). Stochastic Frontier Model for Cost and Profit Efficiency of Islamic Online Banks. Journal of Internet Banking and Commerce, 1-14.

Qayyum, A., \& Riaz, K. (2012). Technical Efficiency of Pakistani Banks: An Application of Bootstrapped Data Envelopment Analysis Approach. World Applied Sciences Journal, 16(12), $1837-1845$.

Qureshi, M. A., Shaikh, M., \& Multan, P. (2012). Efficiency of Islamic and Conventional Banks in Pakistan: A Non-parametric Approach. International Journal of Business and Management, 7(7), 40-50.

Rajhi, W., \& Hassairi, S. A. (2013). Islamic banks and financial stability: A comparative empirical analysis between Mena and Southeast Asian countries. Région et Développement, 37, 149-177.

Regaieg, B., \& Abidi, E. (2015, January). Islamic banks in the time of the credit subprime: a study of the $\mathrm{x}$-efficiency by the SFA method. International Journal of Innovation and Applied Studies, 10(1), 45-59.

Resti, A. (1997). Evaluating the cost-efficiency of the Italian Banking System: What can be learned from the joint application of parametric and non-parametric techniques. Journal of Banking \& Finance, 21(2), 221-250.

Rohani, M., et al. (2008). Assessing production efficiency of Islamic banks and conventional bank Islamic windows in Malaysia. MPRA Paper No. 10670.

Rosita, et al. (2012). Profit Efficiency and Competitiveness of Commercial Banks in Malaysia. World Academy of Science, Engineering and Technology International Journal of Social, Behavioral, Educational, Economic, Business and Industrial Engineering, 6(6), 1277-1280.

Said, A. (2013). Risks and Efficiency in the Islamic Banking Systems: The Case of Selected Islamic Banks in MENA Region. International Journal of Economics and Financial Issues, 3(1), 66-73. 


\section{Ml Macrothink}

International Journal of Accounting and Financial Reporting ISSN 2162-3082

Sakarya, B. (2016). Financial Stability of Islamic (Participation) Banks in Turkey. Munich Personal RePEc Archive, MPRA Paper No. 70634 (pp.1-27).

Sufian, F. (2007). The efficiency of Islamic banking industry: a non-parametric analysis with non-discretionary input variable. Islamic Economic Studies, 14(1\&2), 53-78.

Taylor, B. J. (2009). The financial crisis and the policy responses: an empirical analysis of what went wrong. Working Paper 14631, Cambridge.

Thorsten, B., Asli, D. K., \& Ouarda, M. (2013). Islamic vs. conventional banking: Business model, efficiency and stability. Journal of Banking \& Finance, 37(2), 433-447.

Vander, V. (1996). The effect of mergers and acquisitions on the efficiency and profitability of EC credit institutions. Journal of Banking and Finance, 1531-1558.

Vivas, A. L. (1997). Profit efficiency for Spanish savings banks. European Journal of Operational Research, 98, 381-394.

Weill, L. (2002). Does restructuring improve banking efficiency in a transition economy?. Applied Economics Letters, 9(5), 279-281.

Weill, L. (2004). Measuring Cost Efficiency in European Banking: A Comparison of Frontier Techniques. Journal of Productivity Analysis, 21(2), 133-152.

Weill, L. (2010). Do Islamic banks have greater maker power?. Comparative Economic Studies, 53(2), 291-306.

Yudistira, D. (2003). Efficiency in Islamic banking: An empirical analysis of eighteen banks. Donsyah Yudistira Islamic Economic Studies, 12(1), 2-19.

\section{Notes}

Note 1. Srinivas Talluri (2000): Data Envelopment Analyses: Model and extentions.

Note 2. Its leaders have been accused of concealing billions of dollars of latent losses.

\section{Copyright Disclaimer}

Copyright for this article is retained by the author(s), with first publication rights granted to the journal.

This is an open-access article distributed under the terms and conditions of the Creative Commons Attribution license (http://creativecommons.org/licenses/by/4.0/) 